\title{
ANALISIS NILAI PERUSAHAAN PADA IMPLEMENTASI PROGRAM KEPEMILIKAN SAHAM PADA KARYAWAN/MANAJEMEN
}

\author{
Dwitya Aribawa \\ Fakultas Ekonomi, Universitas Atma Jaya Yogyakarta \\ dwitya_aribawa@mail.uajy.ac.id
}

\begin{abstract}
This research aims to investigate whether there is a significant difference of Economic Value Added (EVA) before and after Employee Stock Ownership Plan (ESOP) or Management Stock Ownership Plan (MSOP) implementation years. It is widely considered that EVA is a complex indicator that also take firms' risk factor (beta) into consideration. We used firms listed on Indonesian Stock Exchange (IDX) as the sampling frame with 17 firms as our final sample, representing various industries. After running data normality test, we performed paired sample t-test to test our hypothesis. The results show that the pre-and post- ESOP implementation years have significantly different EVA.
\end{abstract}

Keywords: Employee Stock Ownership Plan (ESOP), Corporate Valuation, Economic Value Added (EVA)

\begin{abstract}
ABSTRAK
Penelitian ini bertujuan menganalisis economic value added (EVA) sebelum dan sesudah implementasi program kepemilikan saham pada karyawan/ manajemen dengan objek penelitian ini adalah perusahaan publik yang menggunakan kebijakan ESOP/MSOP sebagai sarana benefit/incentive berupa pembagian sebagian saham untuk karyawan/ manajemen. Variabel yang digunakan sebagai indikator nilai perusahaan adalah EVA. Nilai EVA dianggap sebagai indikator yang kompleks dan mempertimbangkan faktor resiko (beta) dari perusahaan. Perusahaan yang dianalisis adalah perusahaan yang listing di Bursa Efek Indonesia. Terdapat 17 perusahaan yang layak untuk dilakukan analisis berdasarkan kriteria yang ditentukan peneliti. Pengumpulan dan data dianalisis secara pooling, hal ini melihat dari tidak dibedakannya perusahaan berdasarkan industri (multi industri). Paired sample test digunakan untuk menguji hipotesis pada penelitian dan sebelumnya dilakukan uji normalitas data. Hasil analisis bahwa hasil perbandingan rata-rata EVA sebelum dan sesudah implementasi program kepemilikan saham pada karyawan/manajemen terdapat perbedaan yag signifikan.
\end{abstract}

Kata Kunci: Program kepemilikan saham karyawan/manajemen, Nilai Perusahaan, EVA, Perusahaan publik Indonesia. 


\section{PENDAHULUAN}

Employee Stock Ownership Plan (ESOP) dan Management Stock Ownership Plan (MSOP) didefinisikan sebagai program yang memberikan kesempatan untuk karyawan dan/atau manajemen untuk berhak memiliki sejumlah lembar saham pada perusahaan tempat mereka bekerja (Rosen, Case, \& Staubus 2005). ESOP dan MSOP dikenal juga dengan program kepemilikan saham karyawan atau Manajemen. Saat ini di Indonesia perusahaan-perusahaan sudah banyak yang mulai mengadopsi konsep ESOP dan MSOP, dapat terlihat dari 11 perusahaan yang termasuk kategori 45 perusahaan paling likuid di Bursa Efek Indonesia atau dikenal dengan LQ-45 (periode Agustus 2016 - Januari 2017) mengadopsi konsep ini (Bursa Efek Indonesia 2016). Ditambah lagi dengan adanya keringanan pajak yang diperoleh perusahaan atas penerbitan saham kepada karyawan/ manajemen sejak tahun 1999. Peraturan perpajakan mengatur bahwa dalam hal saham tersebut diberikan secara cuma-cuma, maka pada saat saham diterbitkan hanya terkena $\mathrm{PPh}$ Pasal 21 atas nilai pasarnya (dalam hal tercatat di Bursa) atau nilai nominalnya (dalam hal tidak diperdagangkan di bursa)(Bapepam 2002).

Pada umumnya dalam pemberian saham kepada karyawan, emiten atau perusahaan publik di Indonesia melaksanakan ESOP atau MSOP dalam bentuk opsi saham atau warrant dengan salah satu tujuan untuk meningkatkan tanggung jawab dan loyalitas manajemen dan karyawan pada perusahaan. Sedangkan, untuk perusahaan non Tbk, ESOP dan MSOP banyak ditemukan pada anak perusahaan dari perusahaan multinasional yang beroperasi di Indonesia. Penerapannya menggunakan cashless exercise yang menyerupai phantom stock atau SARs (hibah berupa saham). Perusahaan-perusahaan terbuka menggunakan peraturan Bapepam Nomor IX.D.4 dan Nomor IX.A.7 sebagai dasar hukum untuk melaksanakan program kepemilikan saham oleh karyawan (Bapepam 2002). Penelitian ini berfokus pada perusahaan publik yang mengadopsi ESOP sebagai salah satu cara membagikan sahamnya.

Dampak dari implementasi ESOP pada nilai perusahaan di Amerika Serikat menunjukkan bahwa implementasi ESOP pada perusahaan memiliki reputasi buruk karena dinilai dari tingginya tingkat resiko kebangkrutan dan berpengaruh pada nilai perusahaan yang mengadopsi ESOP (Ivanov \& Zaima 2011). Berdasarkan Damodaran (2005), dinyatakan bahwa dampak dari ESOP pada perusahaan cukup sulit dilihat dengan pendekatan yang tidak komprehensif. Pada penelitian sebelumnya belum dilakukan pengukuran nilai perusahaan yang komprehensif, dapat dilihat dari indikator nilai perusahaan yang hanya menggunakan analisis rasio profitabilitas dan rasio pasar. Dua rasio tersebut belum memperlihatkan tingkat resiko dari perusahaan. Pada penelitian ini digunakan pendekatan Economic Value Added (EVA) sebagai salah satu indikator yang komprehensif dan akurat dalam pengukuran dari bertambah atau berkurangnya nilai dari sebuah perusahaan, maka pada penelitian ini EVA digunakan sebagai tolak ukur untuk melihat apakah sebuah implementasi ESOP/MSOP berpengaruh pada nilai perusahaan. Penelitian ini 
menganalisis EVA sebelum dan sesudah implementasi program kepemilikan saham pada karyawan/ manajemen pada perusahaan publik yang menggunakan kebijakan ESOP/MSOP sebagai sarana benefit/incentive berupa pembagian sebagian saham untuk karyawan/ manajemen.

\section{KAJIAN PUSTAKA}

\section{Employee Stock Ownership Plan}

ESOP/MSOP merupakan suatu program yang memungkinkan partisipasi karyawan/manajemen untuk memiliki saham perusahaan atau induk perusahaan tempat mereka bekerja (Bapepam 2002). ESOP/MSOP merupakan suatu jenis program jangka panjang yang dirancang untuk menerima kontribusi perusahaan pada suatu pengelola dana (fund) yang akan melakukan investasi pada saham perusahaan untuk kepentingan karyawan (Freeman 2007). Pendekatan ini memungkinkan seorang karyawan berhak memiliki saham dari perusahaan tempatnya bekerja.

Pada teorinya, ESOP/MSOP akan memotivasi penerimanya dengan memberikan timbal balik berupa rasa kepemilikan atau belongingness pada perusahaan. Hal tersebut akan meningkatkan produktivitas karyawan dan dilain pihak juga meningkatkan harga saham. Dengan adanya harga saham meningkat akan berdampak baik untuk shareholders wealth. Ditambah lagi tax benefit yang muncul dari penerapan ESOP akan berdampak positif pada neraca keuangan perusahaan. Di lain pihak ESOP dapat menjadi sebuah dampak negatif pada shareholder lama, dengan kondisi karyawan yang memiliki ESOP tidak memiliki performa baik ataupun bersatu untuk menjatuhkan perusahaan (Brigham \& Ehrhardt 2010)

Dengan suatu program non-leveraged, perusahaan membuat suatu akun trust setiap tahun atas nama masing-masing karyawan, perusahaan akan memberikan sebuah manfaat pada akun tersebut sebagai program pensiun. Manfaat tersebut dapat dibuat dalam bentuk saham (yang memperbaiki arus kas perusahaan karena dapat mengurangi pengeluaran pajak perusahaan), atau dapat juga berbentuk tunai yang kemudian digunakan oleh trust untuk membeli saham perusahaan. Saham yang diperoleh dengan program ini dialokasikan kepada akun-akun perorangan yang dikelola untuk masing-masing karyawan yang berpartisipasi. Para karyawan menerima saldo akun mereka setelah pensiun atau pemberhentian oleh perusahaan (Ivanov \& Zaima 2011).

Sedangkan program leveraged telah menjadi sarana ekuitas yang digunakan secara meluas pada pasar, terutama untuk perusahaan yang berencana untuk go public atau akan diakuisisi oleh seorang penawar. Program ini dapat digunakan oleh pemilik perusahaan sebagai suatu strategi keluar (exit strategy), memungkinkan untuk menjual sahamnya kepada sekelompok karyawan sebesar nilai pada pasar. 
ESOP/MSOP pada perusahaan publik mendanai pembelian dengan melalui suatu pinjaman, yang dijamin oleh perusahaan.

Sebagai incentive untuk menghargai kinerja jangka panjang karyawan pada perusahaan yang menerapkan ESOP/MSOP dimana pendekatan ini merupakan merupakan langkah efektif untuk mengurangi bahkan menghapuskan agency problem dan tentu saja menurunkan agency cost melalui posisi karyawan/manajer yang juga memiliki kepentingan sebagai eksekutif dengan pemegang saham (Ross, Westerfield, \& Jaffe 2008). Kepemilikan saham oleh karyawan perusahaan (insiders) memberi kesan positif untuk investor. Kepemilikan tersebut akan memberikan rasa memiliki yang besar terhadap perusahaan, komitmen yang tinggi dan kontrol pada perusahaan adalah kepuasan tersendiri pada karyawan.

Berdasarkan penelitian sebelumnya ditemukan bahwa 90\% dari karyawan yang menerima incentive dalam bentuk saham menjual saham tersebut sesaat setelah mereka exercise saham tersebut, jadi dapat dilihat bahwa program ESOP/MSOP ini memotivasi karyawan hanya pada waktu yang singkat (Brigham \& Ehrhardt 2010). Penelitian sebelumnya yang menguji hubungan antara pelaksanaan ESOP/MSOP dan nilai perusahaan, bukti-bukti tentang dampak implementasi program ini tergantung pada kinerja perusahaan setelah implementasi ESOP/MSOP yang sangat tergantung pada motivasi karyawan/manajemen terhadap pelaksanaan program ESOP/MSOP di perusahaan.

Saham perusahaan bereaksi negatif terhadap pengumuman dari penerapan program bila digunakan sebagai mekanisme pertahanan anti-pengambilalihan (anti takeover). Hal tersebut karena pasar saham melihat bahwa ESOP/MSOP hanya digunakan untuk sementara sehingga saat kondisi perusahaan stabil maka sahamsaham perusahaan akan kembali dijual dan akan memunculkan fluktuasi pada harga saham. Namun, saham perusahaan mengadopsi ESOP/MSOP bereaksi positif ketika program diadopsi sebagai Leverage Buy Out (LBO) atau penghargaan kepada karyawan (Ivanov \& Zaima 2011). Hal ini dikarenakan perusahaan mendapatkan tax benefit dari penerbitan program ini dan kinerja karyawan yang meningkat (William, Sharon, \& John 2000).

ESOP/MSOP dimanfaatkan oleh perusahaan untuk mengurangi pajak yang harus dibayarkan perrusahaan, motivasi karyawan, dan pertahanan antipengambilalihan. Pengurangan pajak akan meningkatkan tingkat profitabilitas dari perusahaan yang akan berdampak pada value dari perusahaan sedangkan motivasi karyawan yang memegang saham milik perusahaan akan semakin tinggi untuk meningkatkan kinerja perusahaan (Ivanov \& Zaima 2011).

Penerapan ESOP/MSOP di Indonesia belum optimal karena tidak ada perangkat hukum yang mengatur ESOP/MSOP secara khusus, baik ditinjau dari aspek pasar modal, perpajakan, maupun ketenagakerjaan. Hal ini mengakibatkan penerapan ESOP/MSOP dibatasi oleh rambu-rambu hukum yang sesungguhnya tidak 
secara khusus didesain untuk mengatur program ini. Selain itu, untuk perusahaan tertutup yang belum go public tetapi ingin melakukan program ini masih dibatasi dengan ketentuan penawaran umum mengingat belum adanya ketentuan khusus tentang ESOP/MSOP(Bapepam 2002).

\section{Economic Value Added}

EVA (Economic Value Added) adalah ukuran nilai tambah ekonomis (value creation) yang dihasilkan perusahaan sebagai akibat dari aktifitas atau strategi manajemen. EVA yang positif menandakan perusahaan berhasil menciptakan nilai bagi pemilik modal karena perusahaan mampu menghasilkan tingkat penghasilan yang melebihi tingkat biaya modalnya. Hal ini sejalan dengan tujuan untuk memaksimalkan nilai perusahaan. Sebaliknya EVA yang negatif menunjukkan bahwa nilai perusahaan menurun karena tingkat pengembalian lebih rendah daripada biaya modalnya.

Adanya EVA menjadi relevan untuk mengukur kinerja berdasarkan nilai (value) ekonomis yang dihasilkan oleh suatu perusahaan. Dengan adanya EVA, maka pemilik perusahaan akan memberikan imbalan (reward) aktivitas yang menambah nilai dan membuang fasilitas yang merusak atau mengurangi nilai keseluruhan suatu perusahaan dan membantu manajemen dalam hal menetapkan tujuan internal (internal goal setting) perusahaan untuk implikasi jangka panjang dan bukan jangka pendek saja. Dalam hal investasi, hal ini memberikan pedoman untuk keputusan penerimaan suatu proyek (capital budgeting decision), dalam hal mengevaluasi kinerja rutin (performance assessment) manajemen, EVA membantu tercapainya aktivitas yang meningkatkan nilai dari pemegang saham (Brigham dan Ehrhardt 2010)

EVA adalah metode yang digunakan untuk menentukan apakah suatu proyek penganggaran modal akan menyebabkan perubahan positif dalam kesejahteraan pemilik. Penggunaan EVA sangat popular dalam melihat apakah sebuah investasi baik jangka pendek ataupun jangka panjang berkontribusi pada kesejahteraan pemilik atau shareholders. EVA dihitung dengan melihat perbedaan dari Net Operating Profit after Taxes (NOPAT) dan cost of funds dari sebuah investasi. Cost of funds dapat ditemukan dari perkalian antara jumlah capital invested dengan biaya modal perusahaan (Gitman 2010).

Dalam menyusun struktur modal manajemen harus benar-benar mengetahui dan memahami bagaimana komposisi modalnya, bagaimana pendapatannya, darimana sumber modalnya. Dengan adanya penambahan modal maka nilai pemegang saham dan EVA akan mengalami kenaikan (Brigham \& Ehrhardt 2010). Secara general, ESOP/MSOP adoption akan mempengaruhi produktifitas dan nilai perusahaan dari meningkatnya penerbitan ESOP/MSOP pada karyawan, selain itu market price dari saham perusahaan akan meningkat dan menimbulkan kesejahteraan di dua belah pihak baik pemilik perusahaan dan karyawan. Pengaruh ini dikarenakan 
perusahaan memperoleh keuntungan dari penurunan agency cost dan penurunan pajak yang signifikan dimana kedua hal tersebut memberikan benefit untuk pemegang saham dan karyawan (Henry et al., 2007)

Dampak dari implementasi leveraged ESOP/MSOP dan nonleveraged ESOP/MSOP pada nilai perusahaan di Amerika Serikat menunjukkan bahwa implementasi program pada perusahaan memiliki reputasi buruk karena dinilai dari tingginya tingkat bankruptcies dan berpengaruh pada value perusahaan yang mengadopsi ESOP/MSOP (Ivanov \& Zaima 2011). EVA adalah salah satu indikator akurat dalam pengukuran dari bertambah atau berkurangnya value dari sebuah perusahaan, maka pada penelitian ini EVA digunakan sebagai tolak ukur untuk melihat apakah sebuah implementasi ESOP/MSOP berpengaruh pada value perusahaan.

Biaya modal perusahaan telah bertahun-tahun dianggap sebagai bahan penting dalam evaluasi dan perbandingan kinerja keuangan. Karena biaya modal dapat didefinisikan sebagai pengembalian minimum yang diperlukan oleh investor ke perusahaan, dari sudut pandang manajemen itu adalah ukuran dasar kinerja keuangan (Brigham \& Ehrhardt 2010). Nilai perusahaan itu sendiri terdiri dari nilai saat ini (present value) dari free cash flow yang terdiskonto pada biaya modal perusahaan (cost of capital). Oleh karena itu, biaya modal perusahaan secara langsung terkait dengan nilai (value) perusahaan atau EVA, dan pada umumnya, semakin rendah cost of capital maka semakin tinggi nilai perusahaan, ceteris paribus (Ross, Westerfield, \& Jaffe 2008).

Beberapa penelitian sebelumnya menguji hubungan antara pelaksanaan ESOP/MSOP dan nilai perusahaan, hal tersebut sangat tergantung pada motivasi karyawan/manajemen terhadap pelaksanaan program tersebut. Saham perusahaan cenderung bereaksi negatif terhadap pengumuman dari penerapan ESOP/MSOP bila digunakan sebagai mekanisme pertahanan anti-pengambilalihan (anti - takeover), namun, saham perusahaan mengadopsi ESOP bereaksi positif ketika ESOP diadopsi sebagai Leverage Buy Out $(L B O)$ atau penghargaan kepada karyawan (Ivanov \& Zaima 2011).

Secara umum, ESOP/MSOP adoption akan mempengaruhi produktifitas dan nilai perusahaan dari meningkatnya penerbitan ESOP/MSOP pada karyawan, selain itu market price dari saham perusahaan akan meningkat dan menimbulkan kesejahteraan di dua belah pihak baik pemilik perusahaan dan karyawan. Pengaruh ini dikarenakan perusahaan memperoleh keuntungan dari penurunan agency cost dan penurunan pajak yang signifikan dan kedua hal tersebut memberikan benefit untuk pemegang saham lama dan karyawan (Henry et al., 2007)

Dampak dari implementasi program leveraged dan non leveraged pada nilai perusahaan di Amerika Serikat menunjukkan bahwa implementasi ESOP pada perusahaan memiliki reputasi buruk karena dinilai dari tingginya tingkat 
bankruptcies dan berpengaruh pada value perusahaan yang mengadopsi ESOP (Ivanov \& Zaima 2011). EVA adalah salah satu indikator akurat dalam pengukuran dari bertambah atau berkurangnya nilai dari sebuah perusahaan, maka pada penelitian ini EVA digunakan sebagai tolak ukur untuk melihat apakah implementasi ESOP berpengaruh pada value perusahaan. Hipotesis pada penelitian ini diusulkan sebagai berikut.

H1: Terdapat perbedaan signifikan antara economic value added dari perusahaan publik sebelum dengan economic value added sesudah implementasi ESOP.

\section{METODA PENELITIAN}

Unit Analisis dari penelitian ini adalah 17 perusahaan yang pertama kali mengadopsi ESOP/MSOP sejak tahun 2004 sampai dengan 2009. Uji beda layak dilakukan pada periode pengamatan karena dari observasi peneliti perusahaan yang dipilih adalah perusahaan yang tidak berdampak signifikan pada krisis ekonomi global pada 2009. Data yang diperoleh dapat dikatakan representatif untuk memperlihatkan pengaruh dari program ESOP/MSOP. Data EVA diperoleh dari perhitungan yang dilakukan pada data laporan keuangan perusahaan ter-audit yang didapat dari Bursa Efek Indonesia (BEI) dan jenis data yang digunakan ialah pooling data karena menggunakan data dari sektor industri yang berbeda dan dengan time series yang berbeda.

\section{Definisi Operasional Variabel dan Pengukuran}

Variabel yang diuji dalam penelitian ini yaitu Economic Value Added (EVA). Variabel-variabel tersebut memiliki kriteria pengukuran berdasarkan formula yang telah ditentukan. Perhitungan EVA dilakukan setelah menemukan nilai dari WACC tiap perusahaan. Laba bersih setelah pajak dikurangi dengan nilai dari modal yang diinvestasikan atau capital invested. Capital invested diperoleh dengan WACC dikali dengan operating capital dari perusahaan.

Formula perhitungan untuk Economic Value Added

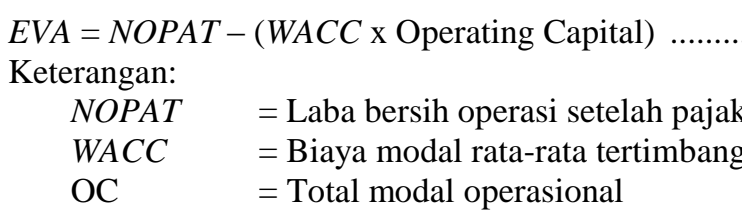

Dari perhitungan akan diperoleh kesimpulan dengan interpretasi, jika $E V A>0$, terjadi nilai tambah ekonomis bagi perusahaan. Jika $E V A<0$, tidak terjadi nilai tambah ekonomis bagi perusahaan. Jika $E V A=0$, hal ini menunjukkan posisi "impas" karena laba telah digunakan untuk membayar kewajiban kepada penyandang dana baik kreditur maupun pemegang saham (Brigham \& Ehrhardt 2010). Proses pengumpulan, pengolahan dan analisis data pada penelitian ini terdiri dari: (1) Mengumpulkan data historis harga saham masing-masing perusahaan, data historis 
IHSG, dan BI Rate (Rf) selama periode pengamatan; (2) Perhitungan proporsi untuk bobot dari masing-masing komponen modal; (3) Perhitungan Beta saham (Reuters) dengan regresi linear dan input data risk premium (Damodaran 2011)(Rm). (4) Menghitung Cost of Equity menggunakan $[\mathrm{CoE}=\mathrm{RF}+\beta *(\mathrm{RM}-\mathrm{RF})]$. , (5) Menghitung Cost of Debt (sebelum pajak) dengan membagi interest expense dengan total liabilities; (6) Menghitung persentase pajak, dengan cara membagi total pajak dengan pendapatan operational (EBT) dikalikan dengan 100\%; (7) Menghitung NOPAT, yaitu mengalikan operating income dengan persentase pajak yang sudah dikurangi satu. [NOPAT = EBT $(1-\mathrm{T})]$.' (8) Menghitung Weighted Average Cost of Capital $(W A C C)$ dengan formula $[W A C C=(\mathrm{CoE} * \mathrm{We})+(\mathrm{CoD}$ after tax $* \mathrm{Wd})] ;(9)$ Menghitung nilai Economic Value Added (EVA) dengan formula [EVA = NOPAT (CI * WACC)]; (10) Melakukan uji normalitas data.; (11) Pengolahan data dengan input nilai EVA secara pooling dan melakukan analisis compare means (paired sample t-test) bila data normal, bila data tidak normal digunakan analisis non parametric ( 2 related sample).

\section{Sampel}

Data sekunder diperoleh dengan observasi waktu ESOP/MSOP Conversion pertama kali yang dilakukan perusahaan dan analisis laporan keuangan yang telah diaudit dari perusahaan untuk memastikan perusahaan memiliki ketebukaan data yang memadai dalam periode pengamatan. Sampel adalah perusahaan yang terdaftar dalam Bursa Efek Indonesia (BEI). Jumlah perusahaan yang mengadopsi ESOP yang dijadikan sampel adalah 17 perusahaan dari berbagai industri.

Tabel 1

Proses Pemilihan Sampel Berdasarkan Kriteria

\begin{tabular}{|c|c|c|}
\hline No & Kriteria Penentuan Sampel & Jumlah Perusahaan \\
\hline 1. & $\begin{array}{l}\text { Observasi Perusahaan } \text { yang melakukan } \\
\text { Conversion. }\end{array}$ & 532 perusahaan \\
\hline 2. & $\begin{array}{l}\text { Perusahaan yang melakukan ESOP/MSOP Conversion pertama } \\
\text { kali pada periode } 2004-2009 \text {. }\end{array}$ & 32 perusahaan \\
\hline 3. & $\begin{array}{l}\text { Analisis kelengkapan data pada laporan keuangan perusahaan } \\
\text { pada periode sebelum dan sesudah ESOP/MSOP Conversion }\end{array}$ & 17 Perusahaan \\
\hline
\end{tabular}

Pemilihan sampel dilakukan dengan metode purposive sampling yaitu pemilihan sampel untuk tujuan tertentu, dengan menetapkan kriteria sebagai berikut: (1) perusahaan tersebut terdaftar di Bursa Efek Indonesia (BEI) pada periode pengamatan sebelum dan sesudah implementasi ESOP/MSOP dan tidak sedang dalam proses delisting pada periode tersebut; (2) sampel yang diambil adalah seluruh perusahaan yang pertama kali mengadopsi ESOP/MSOP dalam rentang periode penelitian (2004 - 2009); (3) saham perusahaan aktif diperdagangkan selama periode pengamatan; (4) mempunyai laporan keuangan yang lengkap dan telah diaudit setiap tahunnya. 
Tabel 2

Sampel Perusahaan

\begin{tabular}{rlllr}
\hline No & Company & Listing & ESOP/MSOP First Listing & \multicolumn{1}{c}{ ESOP Share } \\
\hline 1 & CENT & $01 / 11 / 2001$ & ESOP 19/08/2004 & $25,000,000$ \\
2 & SCMA & $16 / 07 / 2002$ & ESOP 02/06/2008 & $26,251,675$ \\
3 & IDKM & $04 / 10 / 2004$ & ESOP 04/02/2005 & $36,450,500$ \\
4 & MTDL & 1990 & MSOP 26/07/2007 & $4,201,000$ \\
5 & ASGR & 1989 & ESOP 01/01/2004 & $1,159,500$ \\
6 & IATA & $13 / 09 / 2006$ & EMSOP 10/10/2007 \\
7 & TRIM & $31 / 01 / 2000$ & ESOP 29/7/2005 & $9,605,000$ \\
8 & UNTR & $19 / 09 / 1989$ & ESOP 01/01/2004 & $1,260,000$ \\
9 & PGAS & $15 / 12 / 2003$ & EMSOP 13/12/2004 \\
10 & SOBI & $03 / 08 / 1992$ & MSOP 18/04/2008 & $1,277,097,400$ \\
11 & BDMN & $06 / 12 / 1989$ & ESOP 03/01/2006 & $18,717,343,660$ \\
12 & BBCA & $31 / 05 / 2000$ & ESOP 04/01/2004 & $12,765,250$ \\
13 & BNGA & $29 / 11 / 1989$ & ESOP 03/01/2007 & $1,684,732,050$ \\
14 & BNII & $21 / 11 / 1989$ & ESOP 04/01/2007 & $6,129,045,280$ \\
15 & BMRI & $14 / 07 / 2003$ & MSOP 09/01/2007 & $79,849,652$ \\
16 & BBRI & $10 / 11 / 2003$ & MSOP 01/11/2004 & $135,200,500$ \\
17 & WIKA & $29 / 10 / 2007$ & EMSOP 16/12/2009 & $8,068,538,390$ \\
\hline
\end{tabular}

Sumber: Bursa Efek Indonesia

\section{ANALISIS DAN PEMBAHASAN}

\section{Uji Normalitas Data}

Pengujian normalitas dengan Kolmogorof Smirnov menunjukkan bahwa data EVA memiliki distribusi yang normal ( $\mathrm{Sig}>0,05$ ). Pengujian hipotesis dengan compare means - paired sample test disajikan pada tabel 3.

Tabel 3

Hasil Pengujian Hipotesis

\begin{tabular}{lll}
\hline \multicolumn{1}{c}{ Parameter } & EVA Sebelum ESOP/MSOP & \multicolumn{1}{c}{$\begin{array}{c}\text { EVA Sesudah } \\
\text { ESOP/MSOP }\end{array}$} \\
\hline Sample & 17 & 17 \\
Rata-rata (mean) & 471.651 & 1.340 .855 \\
Standar deviasi & $810.857,3$ & 1.912 .826 \\
Uji Normalitas Kolmogorov- & 0,111 & 0,120 \\
Smirnov Z Sig (2-tailed) & & \\
Paired Sample Test & 0,009 & \\
Sig (2-Tailed) & & \\
\hline
\end{tabular}

Sumber: Hasil pengolahan data sekunder

Nilai rata-rata $E V A$ sebelum dan rata-rata $E V A$ sesudah implementasi ESOP/MSOP pada perusahaan publik yang pertama kali melakukan ESOP adoption sejak tahun 2004 sampai dengan 2009 ditemukan mean (rata-rata) dari EVA sebelum 
implementasi ESOP adalah Rp 471.651 sedangkan nilai mean EVA setelah implementasi ESOP/MSOP adalah Rp1.340.855. Jadi dapat dilihat bahwa terdapat peningkatan dari nilai EVA setelah implementasi ESOP, dengan nilai yang cukup signifikan (EVA meningkat sebesar Rp869.204). Dari tabel paired sample correlation dapat dilihat korelasi positf antara EVA sebelum dan sesudah implementasi dari ESOP/MSOP pada perusahaan publik dimana nilai korelasi 0,939 dengan nilai signifikansi 0,000 (sig < 0,005). Dari tabel ini dapat diambil kesimpulan terdapat hubungan positif antara EVA sebelum dan EVA setelah implementasi ESOP/MSOP dilihat dari data rata-rata EVA. Dari tabel paired sample test, dilihat dari sig. (2tailed) memiliki nilai signifikansi 0,009, nilai ini lebih kecil dari nilai signifikansi 0,05. Jadi dapat diambil kesimpulan yaitu hipotesis didukung yaitu terdapat perbedaan signifikan antara economic value added dari perusahaan publik sebelum dan sesudah implementasi ESOP/MSOP.

Economic value added (EVA) pada perusahaan publik yang melakukan implementasi ESOP/MSOP diketahui memiliki hasil perbandingan antara rata-rata EVA sebelum implementasi ESOP dengan rata-rata EVA sesudah implementasi ESOP/MSOP memiliki nilai signifikansi (2-tailed) 0,009. Nilai ini lebih kecil dari nilai signifikansi 0,05 . Untuk variabel $E V A$ sejalan dengan penelitian sebelumnya yang menyatakan bahwa dampak dari implementasi Leveraged dan non Leveraged pada nilai perusahaan di Amerika Serikat menunjukkan bahwa implementasi ESOP pada perusahaan berpengaruh pada value perusahaan yang mengadopsi ESOP (Ivanov dan Zaima 2011).

Implementasi ESOP/MSOP mengakibatkan perusahaan mendapatkan tax benefit, hal ini dikarenakan perusahaan atau karyawan hanya akan dikenakan pajak penghasilan pribadi dalam penerbitan ESOP/MSOP dibandingkan perusahaan menerbitkan saham pada publik atau mengambil sebuah hutang jangka panjang (Brigham dan Ehrhardt 2010). Berkurangnya pajak yang dibayarkan pada perusahaan secara langsung akan memperbaiki neraca pendapatan yang dimiliki perusahaan, dimana pada neraca tersebut memiliki NOPAT sebagai nilai pendapatan bersih dari sebuah perusahaan dalam satu periode. NOPAT disini berperan dalam penentuan value pada perusahaan untuk perhitungan EVA. Semakin tinggi NOPAT maka nilai dari EVA juga akan semakin tinggi, ceteris paribus. Dengan adanya tax benefit ini maka akan terjadi perubahan jumlah pada NOPAT perusahaan (dapat dilihat pada lampiran) dimana hal ini berdampak pada perubahan nilai akhir dari EVA. Hasil dari penelitian ini juga sejalan dengan penelitian sebelumnya yang menyatakan, penerapan program ESOP/MSOP akan mempengaruhi nilai perusahaan dari meningkatnya penerbitan ESOP pada karyawan/ manajemen. Pengaruh ini dikarenakan perusahaan memperoleh keuntungan dari penurunan agency cost dan penurunan pajak yang signifikan dan kedua hal tersebut memberikan manfaat untuk pemegang saham lama dan karyawan/manajemen (Henry et al., 2007).

Berdasarkan Sanjaya (2012), program ESOP/MSOP ini memiliki tingkat efektifitas yang tinggi bagi perusahaan yang memiliki kepemilikan saham yang tersebar dibandingkan terpusat pada beberapa individu (atau keluarga). Hal ini 
dikarenakan karena masalah keagenan (agency cost) antara karyawan/manajemen dengan pemilik perusahaan (shareholders) sering muncul di perusahaan yang memiliki sebaran pemegang saham yang tinggi di dalamnya. ESOP/MSOP sebagai sarana untuk mengurangi masalah keagenan ini akan lebih efektif untuk mengatasi masalah tersebut.

\section{SIMPULAN, KETERBATASAN DAN SARAN}

\section{Kesimpulan}

Penelitian ini bertujuan untuk melihat pengaruh dari ESOP adoption pada perusahaan publik di Indonesia terhadap economic value added. EVA merupakan tolak ukur dari nilai perusahaan. Berdasarkan hasil dari analisis statistik ditarik kesimpulan bahwa terdapat perbedaan signifikan antara rata-rata $E V A$ sebelum dan sesudah implementasi program kepemilikan saham pada karyawan/manajemen.

\section{Implikasi Manajerial}

Penerbitan ESOP/MSOP ditentukan pada Rapat Umum Pemegang Saham (RUPS), maka pada perusahaan yang belum mengadopsi ESOP/MSOP sebagai salah satu sarana pendistribusian saham pada karyawan/manajemen perlu mempertimbangkan program ini sebagai salah satu incentive/benefit yang sesuai untuk mengurangi biaya dan masalah keagenan. Program ini juga dipercaya dapat meningkatkan kinerja dan motivasi karyawan juga akan meningkatkan laba akhir dari perusahaan karena tax benefit yang diciptakan oleh ESOP/MSOP.

Hasil penelitian ini memberikan informasi kepada para investor, bahwa dilihat untuk jangka panjang perusahaan yang mengadopsi ESOP/MSOP memiliki kecenderungan kinerja keuangan yang baik, sehingga secara langsung akan berdampak pada harga saham yang relatif meningkat seiring berjalannya waktu. Pada perusahaan di Indonesia yang hendak mengadopsi ESOP/MSOP pada perusahaan sebaiknya melihat program ini sebagai insentif yang diberikan kepada karyawan untuk meningkatkan kinerja atau produktivitas karyawan bukan sebagai jalan keluar untuk anti-takeover dari perusahaan lain ataupun sebagai sarana meningkatkan harga saham.

Pemerintah (Bapepam, saat ini OJK) sebaiknya melakukan evaluasi regulasi dan aturan hukum secara berkala untuk penerbitan ESOP/MSOP. Info terakhir menyatakan pihak Bapepam-LK masih meminta masukan dari pelaku saham di bursa untuk peraturan yang baik untuk seluruh pihak terkait (Infobank 2011).

\section{Keterbatasan Penelitian}

Saat ini di Indonesia, ESOP/MSOP merupakan hal yang masih belum banyak digunakan oleh perusahaan, sehingga belum banyak yang mengetahui apa sebetulnya esensi dari ESOP/MSOP bagi investor dan perusahaan. Terdapat pandangan bahwa 
penggunaan ESOP/MSOP akan mengurangi nilai dari pemegang saham saat ini (Stockholders Values) seperti yang dinyatakan Poulain-Rehm dan Lepers (2013). Penelitian ini terbatas pada perusahaan publik yang mengadopsi EOSP/MSOP di Indonesia, dimana jumlah perusahaan tersebut di Indonseia belum terlalu banyak dan tersebar di berbagai industri. Variabel yang diteliti hanya terbatas pada variabel pengukuran nilai perusahaan yaitu EVA.

\section{Saran}

Rentang waktu pengamatan yang lebih panjang diperlukan untuk analisis pengaruh dari ESOP/MSOP terhadap nilai perusahaan untuk mendapatkan data yang lebih akurat. ESOP/MSOP merupakan program jangka panjang yang hasilnya tidak dapat dilihat dalam jangka waktu yang pendek (Ivanov \& Zaima 2011). Penelitian selanjutnya dapat menganalisis pengaruh program kepemilikan saham pada karyawan/manajemen pada produktifitas dan profitabilitas perusahaan(Rosen, Case, \& Staubus 2005), nilai pemegang saham (Poulain-Rehm \& Lepers 2013) dan harga saham (Vergos \& Christopoulos 2000). Dampak dari kepemilikan karyawan pada saham perusahaan dapat menimbulkan efek negatif maupun positif pada profitabilitas dan produktivitas karyawan pada perusahaan, hal ini tergantung pada latar belakang perusahaan mengambil keputusan ESOP/MSOP (Kim \& Ouimet 2014). Melakukan penelitian lebih lanjut setelah rangkumnya penyusunan peraturan baru berkaitan dengan permasalahan penerapan ESOP/MSOP oleh perusahaan baik perusahaan publik, non public atau perusahaan multinasional yang akan melakukan ESOP (Bapepam 2002). Sehingga informasi penerbitan ESOP/MSOP oleh perusahaan akan menjadi lebih teratur dan transparan dalam implementasinya oleh perusahaan.

\section{DAFTAR PUSTAKA}

Bapepam. 2002. "Studi penerapan ESOP (Employee Stock Ownership Plan) pada emiten di pasar modal Indonesia."

Brigham, Eugene F., dan Michael C. Ehrhardt. 2010. Financial management: Theory \& practice (13th Edition). Kentucky: South-Western College Pub.

Bursa Efek Indonesia. 2016. "IDX LQ45: Februari 2016.”

Damodaran, Aswath. 2005. "Employee stock options (ESOPs) and restricted stock : Valuation effects and consequences," no. September: 1-52.

_. 2011. "Risk premium." 2011.

Freeman, Steven F. 2007. "Effects of esop adoption and employee ownership : thirty years of research and experience." International Journal of Research in Management, Economics and Commerce 7 (1).

Gitman, Lawrence J. 2010. Principles of managerial finance (12th edition). Boston: Pearson Addison-Wesley. 
Henry, Steve, Joseph Kavanaugh, Robert Stretcher, dan Darla Chisholm. 2007. "Esop firm performance pre- and post-market peak: empirical evidence." Academy of Accounting and Financial Studies Journal 1 (1): 125-42.

Infobank. 2011. "Bapepam: peraturan esop masih terkendala banyak masalah.” 2011.

Ivanov, Stoyu I., dan Janis K. Zaima. 2011. "Analysis of the effects of ESOP adoption on the company cost of capital." Journal of Managerial Finance 37 (2): 173-88. https://doi.org/10.1108/03074351111103695.

Kim, E. Han, dan Paige Ouimet. 2014. "Broad-based employee stock ownership: motives and outcomes." The Journal of Finance 69 (3): 1273-1319. https://doi.org/10.1111/jofi.12150.

Poulain-Rehm, Thierry, dan Xavier Lepers. 2013. "Does employee ownership benefit value creation? the case of france (2001-2005)." Journal of Business Ethics 112 (2): 325-40. https://doi.org/10.1007/s10551-012-1255-0.

Rosen, Corey M., John Case, dan Martin Staubus. 2005. Equity: Why employee ownership is good for america. Massachusetts: Harvard Business School Press.

Ross, Stephen A., Randolph Westerfield, dan Jeffrey Jaffe. 2008. Modern Financial Management (8th edition). USA: Mc Graw Hill, International Edition.

Sanjaya, I Putu Sugiartha. 2012. "The employee stock ownership program phenomena: evidence from indonesia." Review of Business \& Finance Studies 3 (2): 9-20.

Vergos, Konstantinos, dan Apostolos G. Christopoulos. 2000. "Is the issuing of executive stock options a 'positive signal' for the market value of a firm?: the greek evidence." International Journal of Corporate Finance and Accounting (IJCFA) 1 (2): 22-32.

William, N. Pugh, L. Oswald Sharon, dan S. Jahera John. 2000. "The effect of ESOP adoptions on corporate performance." Journal of Managerial and Decision Economics 21 (5): 167-80. https://doi.org/10.1002/mde.971. 